\title{
Using Plant Phenology and Landsat-8 Satellite Data to Quantify Water Use by Onion Crop in the Mesilla Valley, New Mexico
}

\author{
Cantekin KIVRAK $^{1 *}$, A. Salim BAWAZIR ${ }^{1}$, Zohrab SAMANI ${ }^{1}$, Caiti STEELE ${ }^{2}$, Bülent SÖNMEZ ${ }^{3}$ \\ ${ }^{I}$ Dept. of Civil Engineering, New Mexico State University, Las Cruces, NM \\ ${ }^{2}$ Dept. of Plant and Environmental Sci. Jornada Experimental Range Station, NMSU, Las Cruces, NM \\ ${ }^{I}$ MFAL, General Directorate of Agricultural Research and Policies, Ankara, TURKEY
}

\begin{abstract}
Non-storage summer dry onion crop is among the top 10 agricultural commodities in New Mexico (NM), USA. In 2000, NM was ranked the second in the nation as the leading state in growing summer dry onion. According to USDA statistical records, onion production or sales in NM was valued at $\$ 91.4$ million. Mesilla Valley is one of the major onion-producing regions of NM. Due to many years of drought in the region and the concern for climate change, irrigation managers and decision makers are interested in quantifying water use or evapotranspiration (ET) and the number of acreage of onion crop grown in the Valley. This information can then be used for managing the scarce water resources of the region. Plant phenology, Landsat-8 satellite data, and USDA crop data were used to identify onion crops in the Valley (area of about $47,000 \mathrm{ha}$ ) and to determine their consumptive water use or ET using remote sensing Regional ET Estimation Model (REEM) from 2014 through 2016. Time series of NDVI clearly identified Fall and Spring-season onion crops in the Valley. REEM estimated Springseason onion crop maximum ET of $973 \mathrm{~mm}$ in 2015 and $975 \mathrm{~mm}$ in 2016 during the growing season. These values compared reasonably well to ET estimates of 894 and $955 \mathrm{~mm}$ for the same periods (i.e. 2015 and 2016) using FAO-56 crop coefficient based method. The methodology presented could be used in other regions to identify onion crops and their consumptive water use.

Key words: Onion, NDVI, Evapotranspiration, Landsat-8, Remote Sensing
\end{abstract}

\section{INTRODUCTION}

Recently, onion (Allium cepa L.) has become one of the preferred crops by farmers in New Mexico (NM), especially in the Mesilla Valley, Dona Ana County, USA. This preference is in part due to shortage of water in the region, availability of improved onion varieties that are resistant to disease, availability of varieties such as the NuMexs that are uniquely adapted to the region, and improveme $^{1} \mathrm{nt}$ in the harvesting and marketability aspects of the industry in the region. Due to many years of drought in the region and the concern for climate change, irrigation managers and decision makers are interested in quantifying water use or evapotranspiration (ET) and the number of acreage of onion crop grown in the Valley. This information can then be used for managing the scarce water resources of the region. The objectives of this study are to use plant phenology and Landsat- 8 satellite data to identify onion crops in the Valley and to determine their consumptive water use or ET.

According to New Mexico Department of Agriculture and United States Department of Agriculture - National Agricultural Statistics Service (USDA-NASS) (2015 NM Agricultural Statistics, 2016), New Mexico is the second largest producer of onion after

*Corresponding author: cantekin@nmsu.edu 
California. New Mexico produces a total of 155 million $\mathrm{kg}$ of onions, representing 33 percent of United States total production of onion. In New Mexico, 5100 acres (2,064 ha) of non-storage summer onion were planted in 2015 with a total value of production of about 91.4 million US dollars. According to New Mexico Agricultural Statistic Bulletin (2010), 3400 acres (1376 ha) of onions were planted in the Mesilla Valley in 2010. Varieties commonly grown include Nu-Mex, Grano, Granex, Sweet Spanish, and mid-summer.

The onion fields in the Valley are commonly irrigated by flooding using furrows. However, some farmers use drip irrigation. The irrigation water is either pumped from the ground or obtained from the Rio Grande through Elephant Butte Irrigation District (EBID). The EBID manages irrigation water for the farmers in the Valley. Water requirements of onion vary with location and method of irrigation used (Al-Jamal et al., 2000). To obtain optimum yield of 35,000 to $45,000 \mathrm{~kg} / \mathrm{ha}$ of onion, Doorrenbos and Kassam (1986) reported water requirements of $350 \mathrm{~mm}$ to $550 \mathrm{~mm}$ using furrow irrigation.

Different methods have been used by researchers to estimate or measure ET of onions. Al-Jamal et al. (2000) assessed water use of drip, sprinkler and furrow irrigated onions in the Las Cruces, New Mexico in 1994 -1996. They used crop coefficient (kc) and referenced to grass ET using modified Penman equation to estimate actual ET of onion. They also developed a crop production function (i.e. ET versus yield) for the Mesilla Valley. They reported that the maximum water use by spring-season onion during the growing season (February through August) was about $1170 \mathrm{~mm}$ under drip irrigation.
Piccini et al. (2009) measured ET of onion (Texas cultivar Texas Legend) using weighing lysimeter under sprinkler irrigation in 2002- 2003 and 2004-2005 growing seasons in Texas and reported ET of $362 \mathrm{~mm}$ and $438 \mathrm{~mm}$. Lopez-Urrea et al. (2009) study in Spain, reported onion crop ET of $893.3 \mathrm{~mm}$ using weighing lysimeter under sprinkler irrigation system. Other studies such as Kumar et al. (2007), Mermoud et al. (2005), Bandyopadhyay and Mallick (2003), and Meranzova and Babrikov (2002) used water balance model to estimate ET of onions. Kumar et al. (2007) reported that maximum ET of onions was $379 \mathrm{~mm}$ in India. Bandyopadhyay and Mallick (2003) study also in India found that maximum water use of onions was $254.8 \mathrm{~mm}$. de Olalla et al. (2004) reported onion ET in Spain of 744.7 mm using FAO-56 crop coefficient with ASCE-EWRI (2005) referenced to grass ET method. A summary of onion ET reported in literature is presented in Table 1.

Satellite remote sensing technology has recently become one of the preferred methods for estimating ET of crops, classifying of crop types, soil erosion, change in ecology, and among other uses in a large area. Several ET models have been developed such as Regional ET Estimation Model (REEM), Surface Energy Balance Algorithm for Land (SEBAL), Mapping EvapoTranspiration using high Resolution and Internalized Calibration (METRIC), and others (Samani et al., 2009; Allen et al., 2005; Bastiaanssen et al., 1998a,b; Bastiaanssen et al., 2005). Most remote sensing models estimate ET based on the energy budget principle. In this study, REEM was used to determine ET of onions in the Mesilla Valley. 


\section{LOCATION AND CLIMATE}

Mesilla Valley is located in the southern part of New Mexico, USA in the Dona Ana County (Figure 1). The Valley extends from Leasburg Dam to the border of New Mexico-Texas, USA and Republic of Mexico. The area encompasses about 47,000 ha of mainly agricultural land which was formed historically by the meandering of the Rio Grande; the Rio Grande rans through the Valley. Las Cruces is the major city located in the Valley as shown in Figure 1.

Crops in the Valley are irrigated with either surface water from the Rio Grande or groundwater. Agriculture is the major industry of the area and consumes highest percentage of water in the Valley. Major crops grown in the Valley include Pecan, Alfalfa, cotton and chile.

Climate of the region is typical of semi-arid and is characterized by low and variable precipitation, large diurnal and moderate temperature ranges, low average relative humidity and copious sunshine (Malm, 2003). The mean annual precipitation is $222 \mathrm{~mm}$ based on 109 years of historical record as reported by Malm (2003). Climate data used in this study was obtained from Leyendecker II climate station (Lat: $32^{\circ} 12^{\prime} 03^{\prime \prime}$ and Long: $-106^{\circ} 44^{\prime} 34^{\prime \prime}$ ) for 2015 and 2016. This climate station is located near the center of the Valley at New Mexico State UniversityLeyendecker Plant Science Research Center. Air temperature, relative humidity, solar radiation, precipitation and wind speed were collected at this station (Figure 2). Annual precipitation measured in 2015 was $256 \mathrm{~mm}$. In 2016, precipitation gauge at the Leyendecker II station malfunctioned but a nearby climate station at NMSU measured total precipitation of $204 \mathrm{~mm}$. The air temperature measured ranged from -10.29 to $39.48{ }^{\circ} \mathrm{C}$ in 2015 and -9.81 to $41.79{ }^{\circ} \mathrm{C}$ in 2016 , relative humidity averaged $52.49 \%$ in 2015 and $47.71 \%$ in 2016, and annual solar radiation during 2015 and 2016 totaled 7141 and $7431 \mathrm{MJ} / \mathrm{m}^{2}$, respectively. The windspeed fluctuates during the day averaging to about $2.0 \mathrm{~m} / \mathrm{s}$ with a maximum of $6 \mathrm{~m} / \mathrm{s}$. Gusty winds are common during the early and late part of the year (Jan - April and October December).

\section{METHODOLOGY}

Fields of onion crops in the Mesilla Valley were identified using USDA-NASS crop data. The USDA data, which included several crops grown in the Valley for 2014 through 2016, were imported into Arc-GIS software and 20 fields of onion crops were randomly chosen for this study. Thirteen Landsat- 8 satellite images of clear sky days for 2014-2015 and 2015-2016 growing seasons were downloaded from www.earthexplorer.usgs.gov and processed using $\mathrm{ENVI}^{\circledR}$ software (Research Systems, Inc., Boulder, CO, USA). The processing of images included radiometric calibration. Normalized Difference Vegetation Index (NDVI), albedo ( $\alpha$ ), and land surface temperature (LST) for the Valley were then calculated from the Landsat- 8 data. Using these parameters and ground measured climate data, ET of the Valley was calculated using REEM. The NDVI was also used to identify fall-season and spring-season onion crop fields. 
Table 1. Evapotranspiration of onion crop reported by various authors

\begin{tabular}{|c|c|c|c|}
\hline Author & Method & ET (mm) & Location \\
\hline Piccini et al. (2009) & $\begin{array}{c}\text { Weighing lysimeters } \\
\text { under sprinkler irrigation } \\
\text { system }\end{array}$ & $362-438$ & Texas \\
\hline $\begin{array}{l}\text { Lopez-Urrea et al. } \\
\qquad(2009)\end{array}$ & $\begin{array}{l}\text { Weighing lysimeters } \\
\text { under sprinkler irrigation } \\
\text { system }\end{array}$ & 893.34 & Spain \\
\hline Huang et al. (2016) & $\begin{array}{l}\text { Weighing lysimeters } \\
\text { under mulch of plastic } \\
\text { film }\end{array}$ & $\begin{array}{c}357 \mathrm{~mm}-263 \\
\mathrm{~mm} \text { and } 200 \\
\mathrm{~mm}\end{array}$ & China \\
\hline Kumar et al. (2007) & Water Balance equation & $\begin{array}{c}234 \mathrm{~mm} \text { to } 380 \\
\mathrm{~mm}\end{array}$ & India \\
\hline $\begin{array}{l}\text { Mermoud et al. } \\
\text { (2005) }\end{array}$ & Water balance equation & $\begin{array}{c}571 \mathrm{~mm} \\
\text { to } 735 \mathrm{~mm}\end{array}$ & Switzerland \\
\hline $\begin{array}{l}\text { Bandyopadhyay et al. } \\
\qquad(2003)\end{array}$ & Water balance equation & $254.82 \mathrm{~mm}$ & India \\
\hline $\begin{array}{l}\text { Meranzova et al. } \\
\qquad(2002)\end{array}$ & Water balance equation & $337.84 \mathrm{~mm}$ & Portugal \\
\hline Al Jamal et al. (2000) & $\begin{array}{l}\text { Crop coefficient with } \\
\text { Modified Penman under } \\
\text { drip, sprinkler and furrow } \\
\text { irrigation }\end{array}$ & $1170 \mathrm{~mm}$ & New Mexico \\
\hline de Olalla et al. (2004) & $\begin{array}{l}\text { FAO crop coefficient with } \\
\text { Penman- Monteith }\end{array}$ & $744.7 \mathrm{~mm}$ & Spain \\
\hline
\end{tabular}

Landsat-8 Operational Land Imager (OLI) and Thermal Infrared Sensor (TIRS) images as described by Barsi et al. (2014) consist of 9 spectral bands with their respective wavelengths and resolutions. The approximate size of the scenes from Landsat8 are approximately $170 \mathrm{~km}$ in the north-south and by $183 \mathrm{~km}$ in the east-west directions.

Although there are several vegetation indices, the NDVI is one of the significant vegetation index for monitoring seasonal changes of vegetation growth (Jensen, J.R., 2007). It was calculated as follows (Rouse et al., 1974):

$$
N D V I=\frac{\rho_{N I R}-\rho_{\text {red }}}{\rho_{N I R}+\rho_{\text {Red }}}
$$

where, $\rho_{\text {NIR }}$ is reflectance in the near-infrared band 5 , and $\rho_{\text {red }}$ is reflectance in the red band 4. The NDVI is a unitless index with values ranging from -1 to +1 . The NDVI values for actively growing dense vegetation are high (approximately 0.6 to 0.9 ) and sparse vegetation or senescing vegetation are in the mid to low range (approximate values of 0.2 to 0.5). Barren soils, water, snow, ice, or clouds have NDVI values of less than 0.2 and in slightly negative range (Montandon \& Small, 2008; Yuan \& Bauer, 2007; Bhandari et al.,2012; Gandhi et al., 2015). 


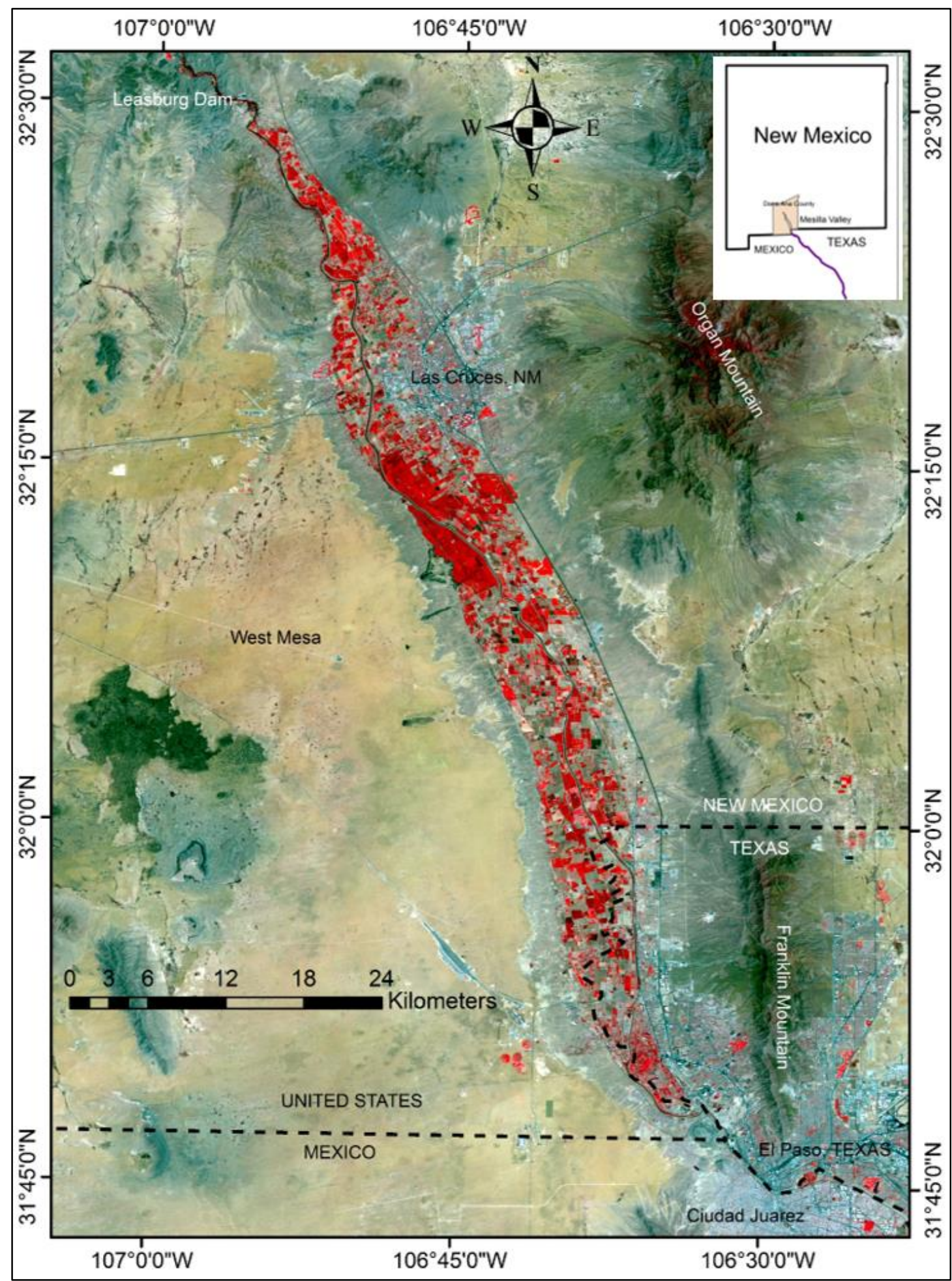

Figure 1. Location of agricultural area in the Mesilla Valley in the Dona Ana County, New Mexico 

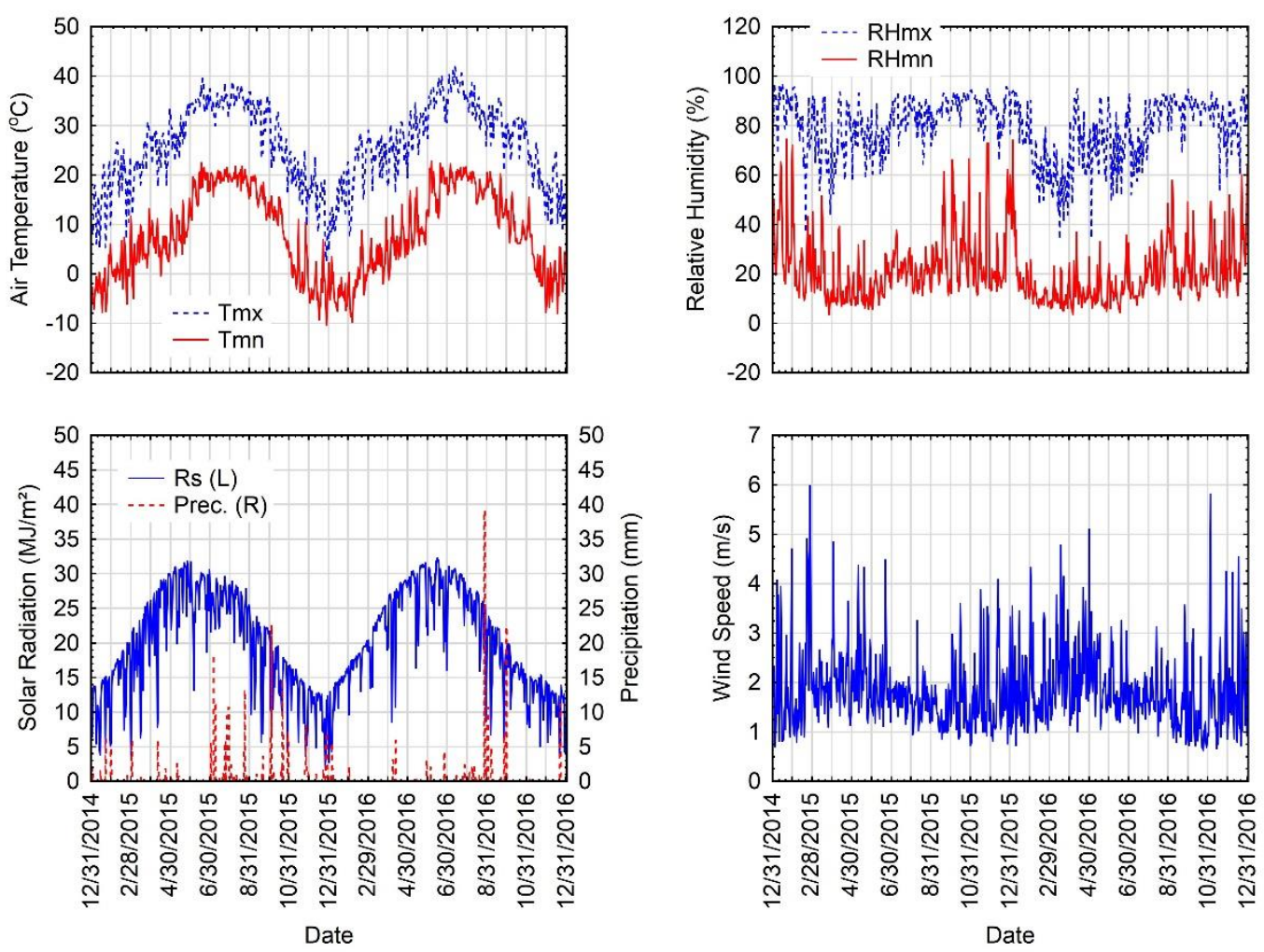

Figure 2. Daily climate data collected at Leyendecker II climate station, Mesilla Valley, New Mexico

Albedo was calculated using the methodology described by Liang (2001) which was initially developed for bands of Landsat-5 and 7. The same equation is used in this study but with Landsat- 8 bands,

$$
\begin{aligned}
\alpha=0.356 \rho_{2}+ & 0.130 \rho_{4}+0.373 \rho_{5} \\
+ & 0.085 \rho_{6}+0.072 \rho_{7} \\
& -0.0018
\end{aligned}
$$

where, $\alpha$ is albedo, $\rho_{\mathrm{i}}$ is the reflectance of Landsat- 8 bands $i$, and $i$ is band 2,4,5,6 and 7, respectively.

Land surface temperature (LST) was derived from Landsat-8 thermal infrared band 10. It involves three steps. In the first step, the digital numbers from satellite digital data are converted to at-sensor radiance as explained in the Landsat-8 Data User's Handbook (2016):

$$
L_{\lambda}=M_{L} Q_{C A L}+A_{L}
$$

where, $L_{\lambda}$ is at sensor radiance (Watts $\left./\left(\mathrm{m}^{2} \cdot \mathrm{sr}^{*} \cdot \mu \mathrm{m}\right)\right), \quad M_{L}$ is Band-specific multiplicative scaling factor from the metadata (RADIANCE_MULT_BAND_X, where $X$ is a band number), and $A_{L}$ is Bandspecific additive scaling factor from the metadata (RADIANCE_ADD_BAND_X, 
where $X$ is a band number). In the second step, top of the atmosphere (TOA) radiation is converted to surface radiation as follows (Barsi et al., 2005):

$$
L_{\lambda}^{T O A}=\tau_{\lambda}\left[\varepsilon_{\lambda} L_{\lambda}+\left(1-\varepsilon_{\lambda}\right) L_{\lambda}^{a t m \downarrow}\right]+L_{\lambda}^{a t m \uparrow}
$$

which can be rearranged as:

$$
L_{\lambda}=\frac{1}{\varepsilon_{\lambda}}\left[\frac{L_{\lambda}^{T O A}-L_{\lambda}^{a t m \uparrow}}{\tau_{\lambda}}-\left(1-\varepsilon_{\lambda}\right) L_{\lambda}^{a t m \downarrow}\right]
$$

where, $L_{\lambda}$ is the surface radiation $\left(\mathrm{W} /\left(\mathrm{m}^{2} \mathrm{sr}\right.\right.$ $\mu \mathrm{m})), \varepsilon_{\lambda}$ is the emissivity of surface object (unitless), $\tau_{\lambda}$ is the transmittance (decimal percent), $L_{\lambda}^{T O A}$ is the TOA radiation $\left(\mathrm{W} /\left(\mathrm{m}^{2}\right.\right.$ $\cdot \mathrm{sr} \cdot \mu \mathrm{m})), L_{\lambda}^{a t m \uparrow}$ is the upwelling atmospheric radiation $\left(\mathrm{W} /\left(\mathrm{m}^{2} \cdot \mathrm{sr} \cdot \mu \mathrm{m}\right)\right)$, and $L_{\lambda}^{a t m \downarrow}$ is the downwelling atmospheric radiation $\left(\mathrm{W} /\left(\mathrm{m}^{2}\right.\right.$ $\cdot \mathrm{sr} \cdot \mu \mathrm{m}))$. The upwelling and downwelling atmospheric radiation, and the transmittance values were obtained from web based calculator (www.atmcorr.gsfc.nasa.gov). An emissivity value of 0.986 for agricultural

\section{RESULTS AND DISCUSSION}

Based on USDA crop survey data, onions fields were identified during 2014-2016 growing seasons. According to Corgan et al. (2000), seeding date in southern New Mexico for fall-season onion varieties is from October through November and harvesting date is in June. Seeding dates of spring-season onion varieties are late January through early February and the harvesting dates are from July through early August. Based on this information, NDVI data was analyzed to determine fall-season and spring-season onions. Thirteen Landsat-8 images for 2015 and 2016 (26 total images) of growing seasons were processed and the NDVI values of 20 sampled fields in 2015 and 21 sampled fields in 2016 of onion crops were analyzed. For areas was used (Yu et al., 2014; Sobrino et al., 2004, 2008). In the third step, surface radiation is converted to the LST using Planck equation,

$$
T=\frac{k_{2}}{\ln \left(\frac{k_{1}}{L_{\lambda}}+1\right)}
$$

where, $T$ is temperature $(\mathrm{K}), k_{1}$ and $k_{2}$ are the Landsat calibration constant (774.89 and 1321.08, respectively), and $L_{\lambda}$ is spectral radiance leaving the surface $\left(\mathrm{W} /\left(\mathrm{m}^{2} \cdot \mathrm{sr} \cdot \mu \mathrm{m}\right)\right)$.

In this study, the Regional ET Estimation Model (REEM) was used to calculate ET of onions for the Valley during clear sky days. The details of REEM algorithm is presented in Samani et al. (2012) and Bawazir et al. (2009) and is not discussed in this paper. The model uses satellite images and climate data to determine ET. Evapotranspiration for the entire growing season for the valley was estimated by fitting clear day ETs with a polynomial function to obtain daily values.

each onion crop field of each image, the NDVI values of five pixels in the middle of the field were averaged to determine the field NDVI value. A time series of NDVI values were then plotted as shown in Figure 3. The NDVI values before the planting and after the harvesting of onion crops indicated the fields were either bare soil, flooded, or another type of crop existed in the same field and therefore were not plotted in the graph. For example, some farmers in the Valley plant lettuce as soon as onion is harvested. As shown in Figure 3, time series of average NDVI values clearly indicates Fall and Spring-season onion crops grown in the Mesilla Valley. Time series of NDVI show that while maturity date of fall-season onion is in late April and early May, spring-seeded onion maturity date is in mid-June. With prior knowledge of approximate 
planting and harvesting dates of different cultivars of onion, the time series of satellitebased NDVI can be used to identify their growing period and stage of growth without expensive ground survey.

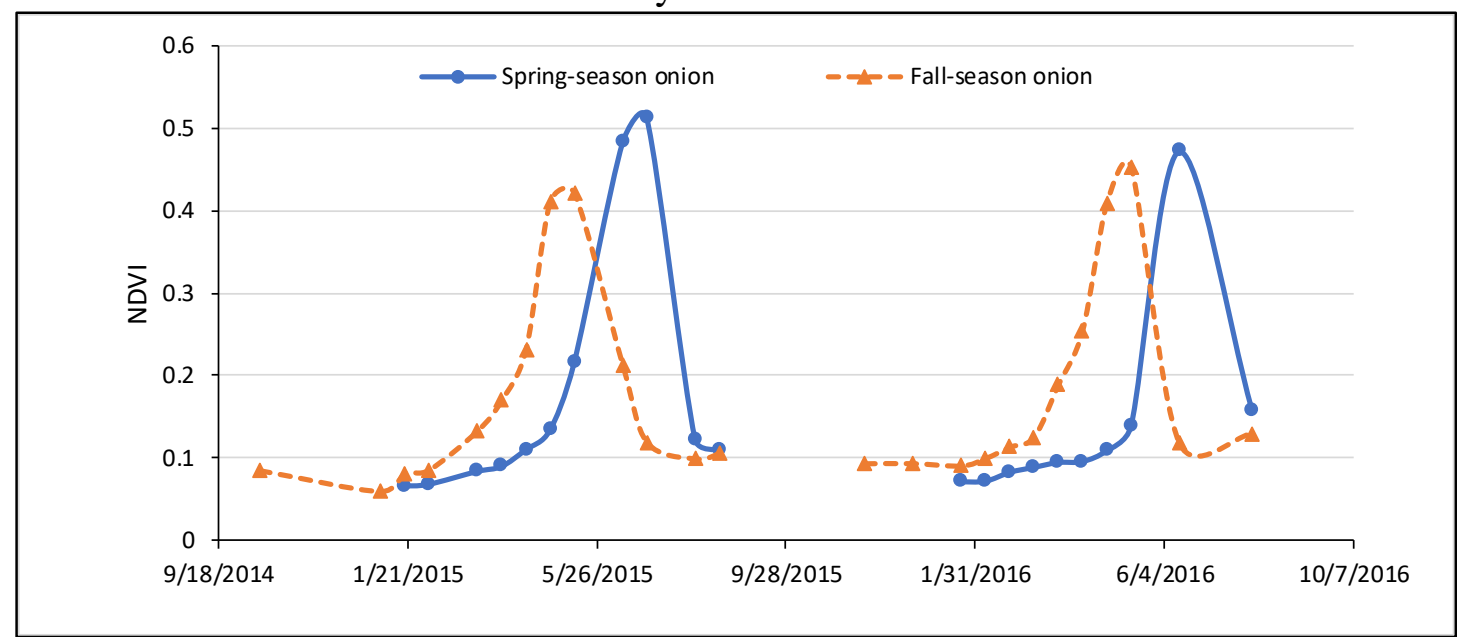

Figure 3.NDVI of Fall and Spring onion grown in the Mesilla Valley, New Mexico

A total of 9 clear-sky Landsat-8 images (4 in 2015 and 5 in 2016) were used in the REEM model to calculate ET for the Mesilla Valley. Similar to NDVI pixel averaging scheme, ET REEM model output of spring season onion crops for 16 fields in 2015 and 19 fields in 2016 spring were obtained. The ET results from REEM varied in space and time as shown in Figures 4. Daily ET values ranged from $0.22 \mathrm{~mm}$ to $9.58 \mathrm{~mm}$. This range of daily ET could be due to different irrigation practices, methods of irrigation, starting dates of planting, or farming practices such as application of fertilizer, management of salinity in soil, etc. An example of ET map of the Mesilla Valley for the month of June 14, 2016 is shown in Figure 5.
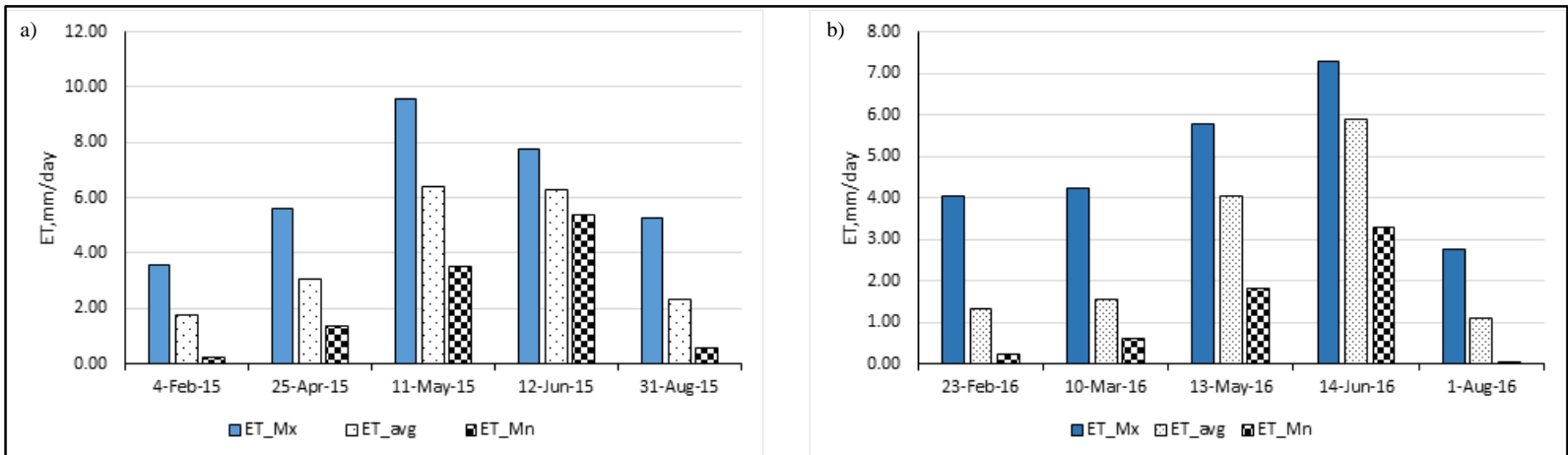

Figure 4. Maximum (Mx), Minimum (Mn) and Average (avg) evapotranspiration (ET) of onion calculated by REEM for (a) 2015 and (b) 2016 growing season

To obtain seasonal ET values, daily maximum, minimum and average ET values for all the fields estimated using REEM were fitted using third-degree polynomial functions as ET versus cumulative growing degree days ( $\Sigma$ GDD):

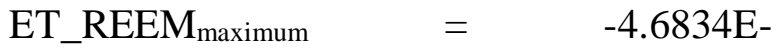
$09\left(\sum \mathrm{GDD}\right)^{3}+1.1586 \mathrm{E}-05\left(\sum \mathrm{GDD}\right)^{2}-$ 
5.1963E-03 $\sum$ GDD +4.7077; $\mathrm{R}^{2}$ is 0.9950, Std. Dev. is 1.75 , and Std. Err. is 0.78 .

ET_REEM average $^{=}-5.2230 \mathrm{E}-09\left(\sum \mathrm{GDD}\right)^{3}+$ $1.2595 \mathrm{E}-05\left(\sum \mathrm{GDD}\right)^{2}$ $-4.4085 \mathrm{E}-$
ET_REEM ${ }_{\text {minimum }}=-3.6491 \mathrm{E}-09\left(\sum \mathrm{GDD}\right)^{3}+$ 9.0964E-06 $\left(\sum \mathrm{GDD}\right)^{2}$ $-3.7978 \mathrm{E}-$ 03 $\sum$ GDD0.7867; $\mathrm{R}^{2}$ is 0.9809 , Std. Dev. is 1.35 , and Std. Err. is 0.61 . $03 \sum \mathrm{GDD}+1.8097 ; \mathrm{R}^{2}$ is 0.9987 , Std. Dev. is 2.10, and Std. Err. is 0.94 .

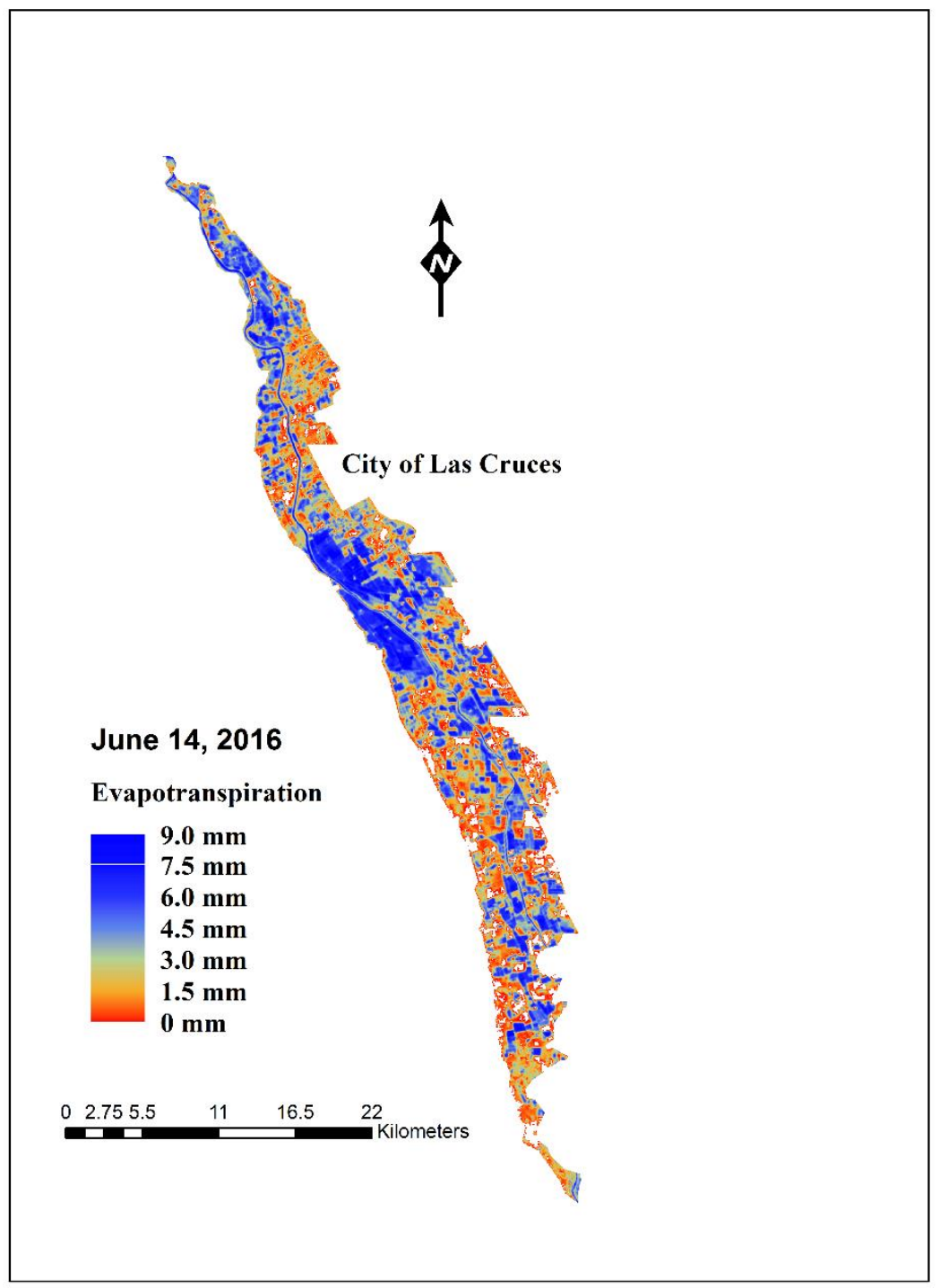

Figure 5. Evapotranspiration map for Mesilla Valley, NM calculated by REEM for June 14, 2016

The GDD was calculated using averaging method in degrees Celsius using maximum cut-off temperature of $21.1^{\circ} \mathrm{C}$ and minimum temperature of $4.44^{\circ} \mathrm{C}$ (Al-Jamal et al., 1999). The ET values obtained from remote sensing
REEM model were compared to FAO-56 (Allen et al., 1998) and Al-Jamal et al. (1999) ET values computed from crop coefficients for 2015 and 2016 growing seasons. FAO-56 crop 
coefficients (Kc) of 0.7 (init.), 1.05 (mid.), and 0.75 (end) were used to calculate ET. AlJamal et al. (1999) third degree Kc polynomial function based on growing degree days for non-stressed onion was used to estimate ET. Daily ET values using the three methods are shown in Figures 6 . Seasonal values are presented in Table 2. The average accumulated ET estimated using REEM model was $610 \mathrm{~mm}$ in 2015 and $611 \mathrm{~mm}$ in 2016. Maximum accumulated ET was 973 $\mathrm{mm}$ in 2015 and $975 \mathrm{~mm}$ in 2016. Maximum accumulated ET from REEM is slightly higher than FAO-56 estimated ET of $899 \mathrm{~mm}$ in 2015 and $955 \mathrm{~mm}$ in 2016. Lowest seasonal ET value found for onion using REEM model was $283.74 \mathrm{~mm}$ in 2015 and $285 \mathrm{~mm}$ in 2016 . Estimated seasonal ET using AL-Jamal (1999) crop coefficient and Modified Penman

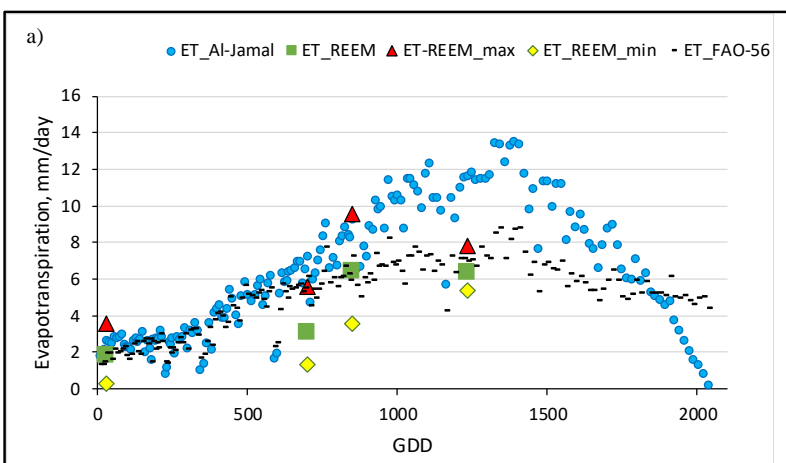

equation were $1156 \mathrm{~mm}$ in 2015 and $1248 \mathrm{~mm}$ in 2016. Their seasonal and daily maximum ET values are much higher than those determined by REEM or FAO-56 (19 to 22\% higher).

The results from this study could be used to classify onion crops grown historically in the region within agricultural areas for decision making and for setting policy of agroeconomic development and future consumptive water use. Once the onion crop fields are identified, their consumptive water use could be estimated using remote sensing model(s). No ground ET measurements were available during 2015 and 2016 to compare with REEM ET estimates. Ground ET measurements are recommended in the future for comparison purposes.

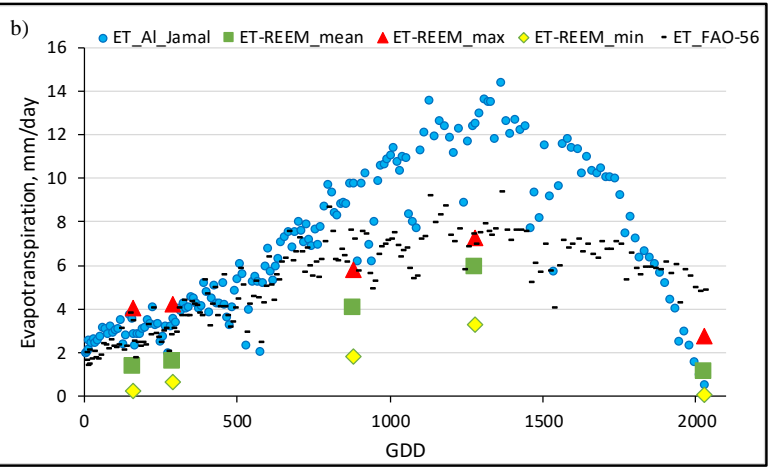

Figure 6. Evapotranspiration (ET) estimation of onion as a function of cumulative growing degree days (cum. GDD) for 2015 (a) and 2016 (b) using Al-Jamal, REEM and FAO-56

Table 2. Growing season evapotranspiration (ET) estimated by REEM, Al-Jamal (Al-Jamal et al., 1999, FAO-56

\begin{tabular}{l|l|l|l|l|l}
\hline \multirow{2}{*}{ Season } & REEM_max & REEM_avg & REEM_min & Al-Jamal & FAO-56 \\
\cline { 2 - 6 } & $\mathrm{mm}$ & $\mathrm{mm}$ & $\mathrm{mm}$ & $\mathrm{mm}$ & $\mathrm{mm}$ \\
\hline 2015 & 973 & 610 & 284 & 1156 & 894 \\
2016 & 975 & 611 & 285 & 1248 & 955 \\
\hline
\end{tabular}




\section{CONCLUSION}

Mesilla Valley could be identified and consumptive water use (or ET) estimated. Plant phenology (NDVI and planting dates) identified fall and spring-season onion crops; Time series of NDVI during 2015 and 2016 clearly indicated Fall and Spring season onion
Landsat- 8 data and plant phenology were used to determine if onion crop in the

crop in the Valley. REEM map of ET showed spatial and temporal variability in ET within the Mesilla Valley. The REEM maximum seasonal ET compared well to FAO-56 ET estimates.

\section{REFERENCES}

Al-Jamal, M. S., Sammis, T. W., Ball, S., \& Smeal, D. (1999). Yield-based, irrigated onion crop coefficients. Applied Engineering in Agriculture, 15(6), 659.

Al-Jamal, M. S., Sammis, T. W., Ball, S., \& Smeal, D. (2000). Computing the crop water production function for onion. Agricultural Water Management, 46(1), 29-41.

Allen, R. G., Pereira, L. S., Raes, D., \& Smith, M. (1998). Crop evapotranspirationGuidelines for computing crop water requirements-FAO Irrigation and drainage paper 56. FAO, Rome, 300(9), D05109.

Allen, R. G., Tasumi, M., Morse, A., \& Trezza, R. (2005). A Landsat-based energy balance and evapotranspiration model in Western US water rights regulation and planning. Irrigation and Drainage Systems, 19(3), 251-268.

ASCE-EWRI. (2005). The ASCE Standardized reference evapotranspiration equation. Reported by the American Society of Civil Engineers (ASCE) Task Committee on Standardization of Reference Evapotranspiration. In: R.G. Allen, I.A. Walter. R.L. Elliot, T.A. Howell, D.
Itenfisu, M.E. Jensen and R.L. Snyder (Eds.), ASCE 0-7844-0805-X, Reston, VA, 204pp.

Bandyopadhyay, P. K., Mallick, S., \& Rana, S. K. (2003). Actual evapotranspiration and crop coefficients of onion (Allium cepa L.) under varying soil moisture levels in the humid tropics of India. TROPICAL AGRICULTURE-LONDON THEN TRINIDAD-, 80(2), 83-90.

Barsi, J. A., Schott, J. R., Palluconi, F. D., \& Hook, S. J. (2005, August). Validation of a web-based atmospheric correction tool for single thermal band instruments. In Optics \& Photonics 2005 (pp. 58820E-58820E). International Society for Optics and Photonics.

Barsi, J.A.; Lee, K.; Kvaran, G.; Markham, B.L.; Pedelty, J.A. (2014). The Spectral Response of the Landsat- 8 Operational Land Imager. Remote Sens. 2014, 6, 10232-10251.

Bastiaanssen, W. G., Menenti, M., Feddes, R. A., \& Holtslag, A. A. M. (1998a). A remote sensing surface energy balance algorithm for land (SEBAL). 1. Formulation. Journal of hydrology, 212, 198-212.

Bastiaanssen, W. G., Pelgrum, H., Wang, J., Ma, Y., Moreno, J. F., Roerink, G. J., \& 
Van der Wal, T. (1998b). A remote sensing surface energy balance algorithm for land (SEBAL).: Part 2: Validation. Journal of hydrology, 212, 213-229.

Bastiaanssen, W. G. M., Noordman, E. J. M., Pelgrum, H., Davids, G., Thoreson, B. P., \& Allen, R. G. (2005). SEBAL model with remotely sensed data to improve waterresources management under actual field conditions. Journal of irrigation and drainage engineering, 131(1), 85-93.

Bawazir, A. S., Samani, Z., Bleiweiss, M., Skaggs, R., \& Schmugge, T. (2009). Using ASTER satellite data to calculate riparian evapotranspiration in the Middle Rio Grande, New Mexico. International journal of remote sensing, 30(21), 55935603.

Bhandari, A. K., Kumar, A., \& Singh, G. K. (2012). Feature extraction using Normalized Difference Vegetation Index (NDVI): a case study of Jabalpur city. Procedia Technology, 6, 612-621.

Corgan, J. N., Wall, M. M., Cramer, C. S., Sammis, T., Lewis, B., \& Schroeder, J. (2000). Bulb onion culture and management. new mexico. Cooperative Extension Service, College of Agriculture and Home Economics, New Mexico State University.

de Santa Olalla, F. M., Domínguez-Padilla, A., \& Lopez, R. (2004). Production and quality of the onion crop (Allium cepa L.) cultivated under controlled deficit irrigation conditions in a semi-arid climate. Agricultural Water Management, 68(1), 77-89.
Doorenbos, J., \& Kassam, A.H. (1986). Yield response to water. FAO Irrig. and Drain, Paper 33. Rome. Italy.

Gandhi, G. M., Parthiban, S., Thummalu, N., \& Christy, A. (2015). Ndvi: Vegetation change detection using remote sensing and GIS-A case study of Vellore district. Procedia Computer Science, 57, 1199-1210.

Jensen, J. R. (2009). Remote sensing of the environment: An earth resource perspective 2/e. Pearson Education India.

Kumar, S., Imtiyaz, M., Kumar, A., \& Singh, R. (2007). Response of onion (Allium cepa L.) to different levels of irrigation water. Agricultural Water Management, 89(1), 161-166.

Liang, S. (2001). Narrowband to broadband conversions of land surface albedo I: Algorithms. Remote Sensing of Environment, 76(2), 213-238.

López-Urrea, R., de Santa Olalla, F. M., Montoro, A., \& López-Fuster, P. (2009). Single and dual crop coefficients and water requirements for onion (Allium cepa L.) under semiarid conditions. Agricultural Water Management, 96(6), 1031-1036.

Malm, N. R. (2003). Climate Guide, Las Cruces, 1892-2000. New Mexico State University, Agricultural Experiment Station.

Meranzova, R., \& Babrikov, T. (2002). Evapotranspiration of long-day onion, irrigated by microsprinklers. Journal of Central European Agriculture, 3(3). 
Mermoud, A., Tamini, T. D., \& Yacouba, H. (2005). Impacts of different irrigation schedules on the water balance components of an onion crop in a semiarid zone. Agricultural water management, 77(1), 282-295.

Montandon, L. M., \& Small, E. E. (2008). The impact of soil reflectance on the quantification of the green vegetation fraction from NDVI. Remote Sensing of Environment, 112(4), 1835-1845.

Piccinni, G., Ko, J., Marek, T., \& Leskovar, D. I. (2009). Crop coefficients specific to multiple phenological stages for evapotranspiration-based irrigation management of onion and spinach. HortScience, 44(2), 421-425.

Rouse Jr, J., Haas, R. H., Schell, J. A., \& Deering, D. W. (1974). Monitoring vegetation systems in the Great Plains with ERTS. Third ERTS Symp.,

Samani, Z., Bawazir, A. S., Bleiweiss, M., Skaggs, R., Longworth, J., Tran, V. D., \& Pinon, A. (2009). Using remote sensing to evaluate the spatial variability of evapotranspiration and crop coefficient in the lower Rio Grande Valley, New Mexico. Irrig Sci 28:93-100

Samani, Z., Skaggs, R., Bawazir, A., Bleiweiss, M., Tran V., Pinon, A. (2012, December). Remote sensing of agricultural water use in New Mexico from theory to practice. New Mexico. Journal of Science,46, 1-16.

Sobrino, J. A., Jiménez-Muñoz, J. C., \& Paolini, L. (2004). Land surface temperature retrieval from LANDSAT
TM 5. Remote Sensing of environment, 90(4), 434-440.

Sobrino, J. A., Jiménez-Muñoz, J. C., Sòria, G., Romaguera, M., Guanter, L., Moreno, J., .. \& Martínez, P. (2008). Land surface emissivity retrieval from different VNIR and TIR sensors. IEEE Transactions on Geoscience and Remote Sensing, 46(2), 316-327.

USDA-NASS \& NMDA (2010). New Mexico Agricultural Statistic Bulletin2010. Las Cruces, NM.

USDA-NASS \& NMDA (2016). 2015 NM Agricultural Statistics. Las Cruces, NM.

USGS, (2016). Landsat 8 (L8) Data Users Handbook. Sioux Falls, South Dakota

Yu, X., Guo, X., \& Wu, Z. (2014). Land surface temperature retrieval from Landsat 8 TIRS - Comparison between radiative transfer equation-based method, split window algorithm and single channel method. Remote Sensing, 6(10), 98299852.

Yuan, F., \& Bauer, M. E. (2007). Comparison of impervious surface area and normalized difference vegetation index as indicators of surface urban heat island effects in Landsat imagery. Remote sensing of Environment, 106(3), 375-386.

Zheng, J., Huang, G., Wang, J., Huang, Q., Pereira, L. S., Xu, X., \& Liu, H. (2013). Effects of water deficits on growth, yield and water productivity of drip-irrigated onion (Allium cepa L.) in an arid region of Northwest China. Irrigation science, 31(5), 995-1008. 